\title{
Correction to: Technical principles of atmospheric carbon dioxide reduction and conversion: economic considerations for some developing countries
}

\author{
Emil Roduner ${ }^{1,2}$ (D) Egmont R. Rohwer ${ }^{1}$
}

Published online: 21 June 2021

(c) The Author(s) 2021

\section{Correction to: \\ Clean Technologies and Environmental Policy (2021) 23:475-482 \\ https://doi.org/10.1007/s10098-020-01889-w}

The article "Technical principles of atmospheric carbon dioxide reduction and conversion: economic considerations for some developing countries", written by Emil Roduner and Egmont R. Rohwer, was originally published Online First without Open Access. After publication in volume 23 , issue 2, page 475-482 the author decided to opt for Open Choice and to make the article an Open Access publication. Therefore, the copyright of the article has been changed to (C) The Author(s) 2021 and the article is forthwith distributed under the terms of the Creative Commons Attribution 4.0 International License, which permits use, sharing, adaptation, distribution and reproduction in any medium or format, as long as you give appropriate credit to the original author(s) and the source, provide a link to the Creative Commons licence, and indicate if changes were made. The images or other third party material in this article are included in the article's Creative Commons licence, unless indicated otherwise in a credit line to the material. If material is not included in the article's Creative Commons licence and your intended use is not permitted by statutory regulation or exceeds the permitted use, you will need to obtain permission directly from the copyright holder. To

The original article can be found online at https://doi.org/10.1007/ s10098-020-01889-w.

Emil Roduner

e.roduner@ipc.uni-stuttgart.de

1 Department of Chemistry, University of Pretoria, Pretoria 0002, South Africa

2 Institute of Physical Chemistry, University of Stuttgart, Pfaffenwaldring 55, 70569 Stuttgart, Germany view a copy of this licence, visit http://creativecommons. org/licenses/by/4.0.

The original article has been corrected.

Open Access This article is licensed under a Creative Commons Attribution 4.0 International License, which permits use, sharing, adaptation, distribution and reproduction in any medium or format, as long as you give appropriate credit to the original author(s) and the source, provide a link to the Creative Commons licence, and indicate if changes were made. The images or other third party material in this article are included in the article's Creative Commons licence, unless indicated otherwise in a credit line to the material. If material is not included in the article's Creative Commons licence and your intended use is not permitted by statutory regulation or exceeds the permitted use, you will need to obtain permission directly from the copyright holder. To view a copy of this licence, visit http://creativecommons.org/licenses/by/4.0/.

Publisher's Note Springer Nature remains neutral with regard to jurisdictional claims in published maps and institutional affiliations. 